\title{
Erratum to: Clinically assessed consequences of workplace physical violence
}

\author{
Jacqueline De Puy $\cdot$ Nathalie Romain-Glassey • \\ Melody Gut • Pascal Wild · Patrice Mangin • \\ Brigitta Danuser
}

Published online: 8 November 2014

(C) Springer-Verlag Berlin Heidelberg 2014

\section{Erratum to: Int Arch Occup Environ Health \\ DOI 10.1007/s00420-014-0950-9}

Unfortunately, the given name and family name of one of the co-author was incorrectly published in the original version. The correct given name and family name should read as Pascal Wild.

The online version of the original article can be found under doi:10.1007/s00420-014-0950-9.

J. De Puy $(\bowtie) \cdot$ N. Romain-Glassey $\cdot$ M. Gut $\cdot$ P. Mangin Centre universitaire romand de médecine léale, Lausanne, Switzerland

e-mail: jacqueline.de-puy@hospvd.ch

P. Wild

Institut national de recherche et de sécurité pour la prévention des accidents du travail et des maladies professionnelles, Nancy,

France

B. Danuser

Institut universitaire romand de santé au travail, Lausanne,

Switzerland 